\title{
Application of finite element method in dental implant research
}

\author{
R. C. VAN STADEN, H. GUAN, Y. C. LOO \\ School of Engineering, Griffith University Gold Coast Campus, Australia
}

Address correspondence to Dr Hong Guan. School of Engineering, Griffith University Gold Coast Campus, PMB 50 Gold Coast Mail Centre, Queensland 9726, Australia. Telephone number: +61 (0)7 5552 8708. Fax number: +61 (0)7 5552 8065. Electronic mail: h.guan@griffith.edu.au 


\begin{abstract}
This article provides a review of the achievements and advancements in dental technology brought about by computer-aided design and the all powerful finite element method of analysis. The scope of the review covers dental implants, jawbone surrounding the implant and the biomechanical implant and jawbone interaction. Prevailing assumptions made in the published finite element analysis, and their limitations are discussed in some detail which helps identify the gaps in research as well as future research direction.
\end{abstract}

Keywords: Dental implant; Implant-jawbone interaction; Design; Finite element analysis

Subject Classification: Engineering application in Dental Implant Research

\title{
1 Introduction
}

Development of an ideal substitute for missing teeth has been one of the long-term aims of dentistry. A dental implant is a biocompatible screw-like titanium 'fixture' that is surgically placed into the jawbone. Figure 1 provides some detail of a typical implant design ${ }^{1}$ and Figure 2 shows its orientation within the jawbone ${ }^{2}$. The implant is anchored in the jawbone. An implant post or abutment and permanent tooth can be attached in a variety of designs.

\section{'[Insert figure 1 and 2 about here]'}

The long-term benefits of dental implants include improved appearance, comfort, speech and self-esteem. With the dental implant, the patient can eat more conveniently and the inconvenience of, and at times embarrassment caused by removable partial and full dentures can be eliminated. In addition the implant is able to protect the remaining natural teeth, stop bone loss and restore facial skeletal structure. As far as the costs are concerned, implants have shown to be less expensive overall than other types of prostheses such as crown and bridge restorations. Currently over three hundred thousand implants are in use in the United States alone. $^{3}$

Worldwide statistics show a high success rate of implantation in excess of $95 \%$ if the implants are correctly designed, manufactured and inserted. Implants are expected to be functioning for a life-long period. This is justified by the fact that the survival rate at 15 years is as high as $90 \%$ if proper and professional cares are taken. Despite all these advantages, only $15 \%$ of Australians have been supplied with single or multiple dental implants. This is mainly due to the lack of general understanding by the dentists of the stress characteristics of implant and jawbone and the biomechanical behaviour of their interaction. Another reason is the lack of clinical skills in consequence of complicated and not well-known insertion technique.

The success of a dental implant depends on a variety of factors including the design of the abutment and technique by which the abutment screw is placed into the implant. Major causes of implant failure are due to insufficient biomechanical bonding between the implant and the surrounding jawbone and also implant tooth fixtures or abutment failure. Insufficient biomechanical bonding might be initiated by, firstly, insufficient osseointegration because of the jawbone not excepting the implant. In this case the only alternative, for a 
single missing tooth, would be to use a bridge. Secondly, after insertion the implant might fail due to the lack of hygiene or overload. A solution would be to insert a new implant after the jawbone has restored itself. Other implant failures could be due to inaccurate design of the tooth fixture leading to overload of the abutment screw and eventually micro fractures within the implant.

Significant similarities exist between dental implants and some mechanical components, for example the bolts used in vehicle engines. The success of the bolt within the engine relies on similar factors to that of the dental implant. These factors might include load applied to bolt/implant and the stress profile within the engine block/jawbone. The dental implant however differs from the engine bolt in that the jawbone is not a rigid body like the engine block. The jawbone usually exhibits an unpredictable biomechanical reaction to the dental implant which complicates the entire implantation and integration process. ${ }^{1}$

The phenomenon of bone response to a foreign insert, such as an implant, has not been studied adequately and the long-term effects of such stresses are still unclear. A thorough understanding of this phenomenon might lead to a reduction in the undesirable stresses produced within the jawbone. Bone is a self-adaptive material which means that when the surrounding stress is changed, the bone tissue structure is adjusted by itself to suit the new loading environment. This is known as the bone remodelling. Such remodelling includes both internal modification of apparent bone density and external alteration of bone shape. Bone remodelling induced by the change of normal biological stress is one of the most important factors causing implant failure. This is the so-called stress-shielding effect. Using the finite element method and parameterised optimum design technique, the stress-shielding effect can be minimised to a maximum extent by performing multiparameter optimisation of implant, thereby guaranteeing the success rate of implantation.

The finite element method (FEM) is a numerical method of analysis for stresses and deformations in structures of any given geometry. The structure is discretized into the so called 'finite elements' connected through nodes. The type, arrangement and total number of elements affect the accuracy of the results. The FEM has become one of the most successful engineering computational methods and most useful analysis tool since the $1960 \mathrm{~s}^{4,5}$ It is showing overwhelming capability and versatility in its application in dentistry. ${ }^{6-23}$ This paper reviews past and current practices in the finite element analysis of dental implants. The achievements and limitations of the existing analysis are discussed and the gap in research is identified. Future research directions are also recommended with particular emphasis on the stress evaluation and design optimisation associated with the implants.

\section{Finite element modelling and analysis techniques}

The jawbone and implants are very complicated structures. It is difficult to establish an accurate and valid three-dimensional (3D) finite element model using conventional modelling techniques. Two-dimensional (2D) representations of implants and jawbone structures were often assumed in previous studies. Some of which also failed to recognise the difference between the cortical and trabecular bones. As such, the calculated results are often far from the actual situation for 2D analysis, hence they cannot be used as a useful guidance to the implant treatment.

Generally previous analysis were conducted by firstly constructing a finite element model, followed by specifying appropriate material properties, loading and boundary conditions so that the desired scenarios can be accurately simulated. Various engineering software packages have been employed to model and simulate both the implant and jawbone. 
Selection of either 2D or 3D analysis would depend on the software capabilities and also the required accuracy of the results. Tables 1 and 2 show the software specification, analysis level as well as the finite element meshing schemes used by various researchers during their analysis of dental implants.

\section{'[Insert table 1 and 2 about here]'}

Accurate and efficient modelling can provide insight and understanding of the complicated nature of a dental implant that is surrounded by the jawbone. The success of modelling depends on the accuracy in simulating the geometry and surface structure of the implant, the material characteristics of the implant and jawbone, the loading and support conditions as well as the biomechanical implant-jawbone interface.

\section{Assumptions made in existing finite element analysis}

FEM has become one of the most successful analysis methods used for solving dental related problems. Not unlike many other finite element applications, certain assumptions need to be made in dealing with complicated implant, jawbone and implant-jawbone interaction problems. In general five major simplifications were made in existing analysis of implant and jawbone structures:

[1] The 2D representation of implant and jawbone structures is adopted based on either the assumption of axial symmetry of loads or geometry. ${ }^{9,25,29}$ A majority of the 2D studies claim that the translation of the clinical condition to a 2D model gives sufficient insight into the behaviour of the jawbone around implants. However the stress in the jawbone predicted by a 2D model is less accurate than that predicted by its 3D counterpart. $^{10}$

[2] In most research reported to date, axially applied static loads have been assumed instead of the more realistic dynamic-cyclic loads directed at the occlusal angle encountered in the jawbone during mastication of food. $^{12}$

[3] The fact that the biomechanical reaction of the jawbone differs for each patient means that it is impossible to model the percentage of osseointegration accurately. A fixed bond between the jawbone and implant along the entire interface has been assumed. This implies that under any loading the relative motion between jawbone and implant does not occur. ${ }^{24,30,31}$

[4] An assumption of homogeneous, linear, elastic material behaviour for the jawbone is used which is characterised by a single Young's modulus and Poisson's ratio. ${ }^{29,33,34}$

[5] The choice of implant design for each patient depends solely on the identification, by the clinician, of the patient's bone type. An incorrect choice might lead to an implant failure. Only four different jawbone structures have been evaluated in the previous research. This might also have led to unrealistic results. ${ }^{35}$

\section{Modelling of implant}

Modelling of the implant involves accurate representation of the implant geometry, taperage, material properties, loading conditions and implant surface structure. Following this, a redesign of the implant geometry can be performed to achieve an optimum stress profile in the surrounding jawbone. Creating an accurate analytical model of a dental implant, using appropriate engineering software, is essential in producing realistic and reliable solutions.

Modelling assumptions and software limitations might have led to a number of inaccuracies within the obtained results. Figure 3 shows a simplified dental implant model, together with the surrounding jawbone, with applied loads in three directions. It is often assumed that the dental implant is rectangular in shape and 
modelled in 2D, with no cutting edges, screw thread and surface structure. A fixed bond (100\% osseointegration) is also often assumed between the implant and jawbone. It was found common in many publications to assume either a vertical, oblique, occlusal, horizontal or a combination of the loads applied to the implant. $8,9,12,24,25,26,30,32,36,37,38,39,40$

\section{'[Insert figure 3 about here]'}

\subsection{Implant geometry}

The implant geometry is an important criterion to evaluate during any analysis that considers the biomechanical influence that the implant has on the surrounding jawbone.

Siegele and Soltesz ${ }^{41}$ investigated the stress distribution generated within the jawbone surrounding different types of dental implants (cylindrical, conical, stepped, screw-shaped, hollow cylindrical) by means of the finite element method. The results demonstrate that different implant shapes lead to significant variations in stress distributions in the jawbone. In particular, implant surfaces with very small radii of curvature (conical) or geometric discontinuities (stepped) imply distinctly higher stresses than smoother shapes (cylindrical, screw-shaped). On the other hand, Holmgren et al. ${ }^{42}$ reported that a stepped cylindrical design is most desirable for stress distribution in the surrounding jawbone.

The implant length and diameter has a significant influence on the stress distribution, within the surrounding jawbone. ${ }^{19,38,40,43,44,45,46,47,48}$ Finite element simulation of stress distribution around implants can be used to determine the optimum length and diameter of the implants that would best dissipate stresses induced by the implantation. Himmlova et al. ${ }^{13}$ used FEA to compute values of von Mises stress at the implant-bone interface for all variations in length and diameter of implants. Maximum stress areas were identified to be located around the implant neck. The maximum decrease in stress $(31.5 \%)$ was found for implants with a diameter ranging from of $3.6 \mathrm{~mm}$ to $4.2 \mathrm{~mm}$. Further stress reduction for the $5.0-\mathrm{mm}$ implant was only $16.4 \%$. An increase in the implant length also led to a decrease in the maximum von Mises equivalent stress values; the implant length, however, was not as influential as that of implant diameter. Note that the length of implant ranges from 8 to $18 \mathrm{~mm}^{13}$

Short implants present superior failure rates. Pierrisnard et al. ${ }^{38}$ investigated the influence of implant length and bicortical anchorage on implant stress distribution. The aim of this theoretical study was to assess to what extent the implant length and bicortical anchorage affect the way stress is transferred to the implant components, the implant abutment, and the surrounding bone. Stress analysis was performed using the finite element method and a 3D linear elastic model was generated. All implants modelled were of the same diameter $(3.75 \mathrm{~mm})$ but varied in length, at 6, 7, 8, 9, 10, 11, and $12 \mathrm{~mm}$. Each implant was modelled with a titanium abutment screw and abutment, a gold cylinder and prosthetic screw, and a ceramic crown. The implants were seated in a supporting bone structure consisting of cortical and cancellous bone. It was concluded that the maximum bone stress was virtually constant, independent of implant length and bicortical anchorage. The maximum implant stress, however, increased somewhat with implant length and bicortical anchorage.

Wide-bodied implants placed in the posterior jaw can suffer a significantly elevated risk of implant failure compared to 'regular-diameter' implants. This may relate to either implant design or the relative relationship of implant to surrounding bone dimensions. Shin et al. ${ }^{49}$ conducted a retrospective study documenting a 5year cumulative survival rate (CSR) of 5-mm-diameter wide-bodied implants in posterior jaws as related to 
identified risk factors and relative host bone site dimensions. During this study it was found that wide-bodied implants had a CSR of 80.9\%, while 'regular-diameter' implants had a CSR of 96.8\%. Differences between wide-bodied and 'regular-diameter' implants was found to be statistically significant. Multivariate analysis demonstrated a significant predictive relationship between overall CSR and the ratio of implant to bone volume. A significant difference found between the CSR of the 'regular-diameter' and wide-bodied implants might be due to the differences in the damping capacity of the initial interfacial tissue. The difference between the CSR found in the maxilla (Mx) and the mandible (Md) has not been discussed although it can be observed that generally CSR in Mx is larger than that in Md. The CSR values of wide-bodied implants which was found in various other studies, are shown in Table 3.

\section{'[Insert table 3 about here]'}

An increase in the diameter of the implant led to a decrease in the CSR value, indicating that the optimum diameter of an implant should be less than that of the wide-bodied implants used in Shin et al.'s work. This suggests that relative determinants of critical bone volume to implant dimensions may need to be considered when planning implant surgery. Implant characteristics found in various studies are shown in Table 4 below.

\section{'[Insert table 4 about here]'}

Many researchers recognized the influence that the implant geometry and the quality of the surrounding jawbone have on the overall success of the implantation, Ivanoff et al. ${ }^{45}$ found that a relationship could be seen between implant failure and implant diameter for $4 \mathrm{~mm}$ diameter implants evaluated between 3 to 5 years following insertion. However, no relationship could be seen between implant failure and jaw type, or bone quality and quantity for implant diameters of 3.75 and $5 \mathrm{~mm}$ between 3 to 5 years following insertion and also for 4 and $5 \mathrm{~mm}$ diameter implants after 5 years following insertion. Neither was any relationship seen between marginal bone loss and bone quality and quantity, implant diameter, or jaw type for implant diameters of 3.75 and $5 \mathrm{~mm}$ between 3 to 5 years following insertion and also for 4 and $5 \mathrm{~mm}$ diameter implants after 5 years following insertion, when tested by multiple linear regression analysis.

\subsection{Taperage}

Dental implants might have a degree of taperage applied to either the entire implant or just the bottom section of the implant. Tapered implants enhances primary stability by compressing the surrounding jawbone during and after implantation. The tapered body also facilitates implant placement between convergent roots, in areas with labial concavities and in immediate extraction sites.

Mailath et al. ${ }^{50}$ compared cylindrical and conical implant shapes exposed to physiological stresses and examined the occurrence of stress concentrations at the site of implant entry into the jawbone. It was reported that cylindrical implants produced a more desirable stress profile than the conical shaped counterparts. The need for tapered implants have been identified due to the fact that the survival rate of oral implants in softquality bone were demonstrated to be inferior to that of implants inserted in good-quality bone.

Astrand et al. ${ }^{51}$ showed that a possible way to increase the survival rate in soft-quality bone may be to use a tapered implant. Such an implant has been developed and manufactured by Nobel Biocare AB, Gothenburg, Sweden (http://www.nobelbiocare.com). ${ }^{52}$ The aim of their study was to compare the outcome of using the tapered Branemark System Mark IV fixture with that of using earlier Branemark fixtures in a controlled prospective study. It was concluded that with regard to survival rate and marginal bone level changes, no 
differences could be demonstrated between the Mark IV tapered implant and the Branemark implants used earlier. However, compared with earlier results of Branemark implants in soft-quality bone, the Mark IV (increased taperage) implant demonstrated an improved survival rate. Friberg et al. ${ }^{53}$ investigated through practical experimentation the tapered implants as compared to the straight cylindrical ones. The tapered implant design resulted in an increased primary stability which may be important when placing implants in jaw regions of type 4 bone.

O'Sullivan et al. ${ }^{54}$ conducted a study to analyse the mechanical performance and the primary and secondary stability characteristics of endosseous titanium implants with 1 degree (EXP1) and 2 degrees (EXP2) of taper when compared with the standard Branemark design (http://www.nobelbiocare.com). ${ }^{52}$ At placement, significantly higher insertion torque (IT) was needed to insert the EXP implants. Resonance frequency analysis (RFA) has been used to quantitatively measure implant stability over time. It has long been a recognized need among dental professionals involved in dental implant therapy. ${ }^{55}$ The measurement is taken with a transducer screwed onto the implant, the piezo elements of which are caused to oscillate. The device records the resonance frequency produced from the implant-bone interface which is displayed graphically. The oscillation of the implant transducer element is recorded as the implant stability quotient (ISQ). ${ }^{56}$ Successful implantations indicate an increase in the recorded RFA value, between the period of surgical insertion and the connection of the abutment. A decrease in the RFA recorded value causes a marginal bone loss which in turn would yield unsuccessful implantation. RFA values were significantly higher for EXP1 implants placed in the tibia but not in the femur. In pooling data from the femur and tibia there was a significant difference. The EXP2 implants failed to insert fully and demonstrated a lower RFA value than may have been expected due to the exposed threads, although this difference was not statistically significant. The results obtained by O'Sullivan et al. $^{54}$ showed that the EXP1 resulted in a better primary stability compared with the standard Branemark design. There was no evidence that the tapered design caused negative bone tissue reactions. Stability due to the taperage was gained during the healing period.

\subsection{Material properties of implant}

The biomechanical properties of an implant are very different to the original tissue. The design and manufacture of artificial materials that are aimed at being used within the human body, is becoming increasingly challenging.

Titanium and bio-ceramic materials, such as hydroxyapatite are extensively used as fabrication materials for dental implant due to their high compatibility with hard tissue and living bone. ${ }^{57}$ Titanium has reasonable stiffness and strength while hydroxyapatite has low stiffness, low strength and high ability to reach full integration with living bone. A number of material properties have been adopted for titanium in previous analysis. These are presented in Table 5, where the Young's modulus of titanium has been taken from 102.2 GPa to $113.8 \mathrm{GPa}$, and the Poisson's ratio, between 0.29 and 0.35 , based on different material testing.

\section{'[Insert table 5 about here]'}

In order to achieve adequate dental implantation of the biomaterial, full integration of the implant with living bone must be guaranteed. Uniform stresses of an optimum magnitude in the implant and jawbone must be satisfied to increase the life of the implant and prevent bone resorption. Hedia and Mahmoud ${ }^{57}$ investigated functionally graded material (FGM) to achieve the above advantages. The optimal materials of the FGM dental implant are found to be a combination of hydroxyapatite and titanium. The finite element investigations have shown that the maximum stress in the bone for the hydroxyapatite/titanium FGM implant 
has been reduced by about $22 \%$ and $28 \%$ respectively compared to currently employed titanium and stainless steel dental implants.

Moroi et al. ${ }^{58}$ found that the hydroxyapatite coating reduced the heat conduction to the surrounding tissue because of its low thermal conductivity. However, thermal stress was induced by thermal expansion of the hydroxyapatite and titanium core. This might influence the success of hydroxyapatite-coated implants because the biomechanical properties of ceramics are sufficiently poor leading to insufficient tensile and shear stresses in the surrounding jawbone. The biomechanical integration between living bone and ceramic are not as successful as that of pure titanium. In addition, this tendency becomes more pronounced when the hydroxyapatite-coating surface extends beyond the cortical bone. It is important to fully understand the mechanical behaviour of a natural tooth, in order to improve dental implant performance within the surrounding jawbone. Table 6 shows the material properties of a natural tooth, adopted by various researchers.

\section{'[Insert table 6 about here]'}

The Young's Modulus of enamel summarised in Table 6 has an unexplained variance that could possibly be due to the fact that different testing techniques were employed. For example, by altering the angle of inclination, with respect to the vertical direction, at which the impact test is used will drastically affect the obtained results for the strength of the enamel. The strength of the enamel will be significantly less if it was impact tested parallel to the tubules of the enamel. For other parts of a tooth, Menicucci et al. ${ }^{30}$ found that Mucosa had a Young's modulus, E of $1 \mathrm{MPa}$ and a Poisson's ratio, v of 0.37. It was also found that Pulp had a Young's modulus, E of $2 \mathrm{MPa}$ and a Poisson's ratio, $\mathrm{v}$ of 0.45 . The natural tooth is the ultimate design for its operation and to truly understand its material properties and function is the key to future implant enhancement. The material property information provided in Tables 5 and 6 should be used as a guide in creating the finite element models of dental implant and jawbone.

\subsection{Loading}

Masticatory forces acting on dental implants can result in undesirable stress within the surrounding jawbone which in turn can cause bone rejection to the implant, leading to eventual failure of the implant. In order to produce accurate predictions of the implant-jawbone behaviour, it is essential to determine realistic loading magnitudes and directions. Richter ${ }^{39}$ investigated the actual loads experienced by teeth during chewing. Four main types of food (rubbery confection, pieces of sausage, carrots, and crackers) were examined for their effects on the load experienced by teeth during chewing. Table 7 shows the typical load level experienced in the vertical, transverse and mesiodistal directions, as indicated in Figure 4.

\section{'[Insert table 7 and figure 4 about here]'}

Haraldson et al. ${ }^{65}$ evaluated the mastication forces and chewing efficiency in nine patients, whom were treated with overdentures on osseointegrated implants in the mandible. The bite force was measured during gentle biting, biting as when chewing and biting with maximal effort. All subjects improved subjectively as well as clinically after treatment. The bite force during gentle biting increased on average from $17.3 \mathrm{~N}$ before treatment to $24.0 \mathrm{~N}$ one yr after treatment. A corresponding improvement of biting as when chewing was also found; from on average $24.0 \mathrm{~N}$ before to $38.7 \mathrm{~N}$ after treatment. The maximal bite force increased from on average $74.6 \mathrm{~N}$ at the baseline examination to $131.5 \mathrm{~N}$ at the one-year follow-up. The chewing efficiency improved from the confidence interval, $\mathrm{Ci}=4$ (Median value) before treatment to $\mathrm{Ci}=2.8$ (Median value) 
after treatment. Which means that the middle value of the patients who experienced an improvement in chewing efficiency improved by a factor of 1.2. It is concluded that treatment with an overdenture supported by osseointegrated implants in the mandible improves oral function compared to the situation before treatment.

To successfully replicate the clinical situation, that an implant might encounter, it is important to understand the loading that is induced by the jawbone muscles unto the implant. Koolstra et al. ${ }^{66}$ constructed a 3D mathematical model of the human masticatory system, containing 16 muscle forces and two joint reaction forces. Maximum possible bite forces were computed using optimisation techniques; the optimisation criterion used was to minimize the relative activity of the most active muscle. The model predicted that at each specific bite point, bite forces can be generated in a wide range of directions, and that the magnitude of the maximum bite force depends on its direction. The relationship between bite force direction and its maximum magnitude depends on bite point location and mandibular position. In general, the direction of the largest possible bite force does not coincide with the direction perpendicular to the occlusal plane, as illustrated in Figure 5.

\section{'[Insert figure 5 about here]’}

A significant amount of investigations have assumed the direction of the load applied to the implant to be in three directions, horizontal, vertical and oblique. Canay et al. ${ }^{9}$ and Tada et al. ${ }^{37}$ both assumed a horizontal load of $50 \mathrm{~N}$ and a vertical load of $100 \mathrm{~N}$ with no oblique forces. Whereas Meijer et al. ${ }^{26}$ assumed a horizontal force of $10 \mathrm{~N}$, vertical force of $35 \mathrm{~N}$ and an oblique force of $70 \mathrm{~N}$ at an angle of 120 degrees from the horizontal, as shown in Figure 6.

\section{'[Insert figure 6 about here]'}

Barbier et al. ${ }^{67}$ found that the horizontal loading of a freestanding implant evoked the largest maximum stresses, although the magnitude of the applied horizontal load was five times smaller than that of the vertical load. Non-axial loading has often been related to marginal bone loss, failure of osseointegration, failure of the implant and/or the prosthetic components and if connected to natural teeth, failure of the cement seal on the natural tooth. ${ }^{68,69,70}$

\subsection{Implant surface structure}

The surface quality of an implant is a combination of physical, chemical, mechanical and morphologic factors. Wennerberg et al. ${ }^{71}$ analyzed four groups of implant surface characteristics, these included group A which was Hydroxyapatite (HA) coated used by Osteobond ${ }^{72}, \mathrm{IMZ}^{73}$, Micro-Vent ${ }^{74}$, Bio-Vent ${ }^{74}$, Impla-Med ${ }^{75}$ and Calcitek ${ }^{76}$. Group B consisted of Titanium plasma-sprayed used by IMZ and group C which was Titanium alloy implants used in industry by Core-Vent ${ }^{74}$, Screw-Vent ${ }^{74}$ and $3 \mathrm{I}^{77}$ Miniplant. Finally group D was commercially pure titanium used in industry by 3I, Impla-Med and Nobelpharma ${ }^{78}$.

Various aspects of surface quality have been studied, some showing the presence of surface contaminants (although the biological implications of these are unclear) and better bone fixation of rough compared to smooth surfaces. Implant surface characteristics have a dramatic effect on the speed and integrity of osseointegration and the maintenance of soft tissue and surrounding jawbone around the implant. Surface modification is initiated by factors such as stress reduction and increased surface area. Hermann et al. ${ }^{79}$ found that the rough/smooth implant surface has a significant effect on marginal bone formation as evaluated by 
standardized longitudinal radiography. Bone remodelling occurs rapidly during the early healing phase after implant placement for non-submerged implants and after abutment connection for submerged implants. Figure 7 shows the difference between a submerged and non-submerged implant. Non-submerged implants are common at the time of insertion; whereas submerged implants are expected after 3 months of healing.

\section{'[Insert figure 7 about here]'}

The finite element method has not been employed widely to evaluate the effect that the surface roughness of the implant has on the stress profile produced within the surrounding jawbone. Ronold et al. ${ }^{80}$ experimentally analysed the optimum value for titanium implant roughness in bone attachment using a tensile test. The results supported observations from earlier studies that suggested an optimal surface roughness for bone attachment to be in the range between 3.62 and 3.90 micro-millimetres. The analysis also indicated that a further attachment depend on mechanical interlocking between bone and implant.

Wennerberg and Albrektsson ${ }^{81}$ found that an implant with increased surface roughness leads to a more rapid bone response, particularly to the intermediate rough surfaces $(1-1.5 \mu \mathrm{m})$. The implant surface roughness was determined using the RMS (root mean square) roughness 'equation (1)', as shown below:

$$
\text { RMS Roughness }=\left\{1 / n \sum_{\chi=0}^{n}[s(\chi)-\overline{s(\chi)}]^{2}\right\}^{0.5}
$$

where, $s(\chi)$ is the surface height at point $x$ in the surface profile, $\overline{s(\chi)}$ is the average height of the surface profile and, $\mathrm{n}$ is number of samples collected. ${ }^{82}$ These surfaces have in general been compared to the socalled machined or turned surfaces, with little emphasis being paid to the range of surface textures that might exist within a machined screw implant. For crestal bone, Hansson ${ }^{83}$ compared implants with smooth necks to those with screw thread along the entire implant to bone contact surface. It was found that a major decrease in peak interfacial shear stresses occurred if the entire implant to bone contact had a screw thread. It was concluded that the implants with screw thread along the entire surface would counteract marginal bone resorption in accordance with Wolff's law $^{84}$. It has been found by various authors ${ }^{85,86}$ that the osseointegration of the implant to the surrounding jawbone can be enhanced by simply increasing the surface area of the implant body. Contradictory to Pelsoczi et al. ${ }^{85}$ and Misch et al. ${ }^{86}$, Rokni et al. ${ }^{87}$ found that the implant surface area had insignificant affects on the steady-state crestal bone levels in partially edentulous patients treated with sintered porous-surfaced dental implants.

Threaded implants have an advantage when compared to un-threaded but porous surfaced implants, such as the Endopore ${ }^{88}$ design. With threaded implants a primary stability is achieved through the thread design however the fixation which occurs at the bone-implant interface, can allow for rotational movement. Whereas a porous design greatly increases the surface area at the interface between bone and implant and hence shorter implants can be used. This, in turn, means that Endopore implants can be used in applications for which much longer, threaded implants would be unsuitable. Clinical, radiographic and histological examinations of the Endopore design, have demonstrated that shorter implants, shorter initial healing periods and simpler surgical techniques can be obtained. ${ }^{89}$ These results have been demonstrated to be consistent in a clinical setting, where success rates exceed 96\%. 


\section{Modelling of jawbone}

The primary difficulty in simulating the mechanical behaviour of dental implants is the modelling of human bone tissue and its response to applied mechanical forces. The substantial complexity of the mechanical characteristics of bone and its interaction with implant systems has led to major and often incorrect simplifications made in previous analysis.

Being a self-adaptive material, jawbone needs to be stimulated in order to be retained. A sufficiently low stress would lead to bone loss whereas large stress can cause implant-jawbone interface failure. The ultimate aim during implantation is to achieve the optimum stress profile within the surrounding jawbone. Rieger et al. $^{20}$ and O'Mahony et al. ${ }^{36}$ both assumed that the target stress level for maximum bone growth occurs at 250psi (1.72 MPa) levelling off to a control level at 400psi (2.76 MPa). The stresses depend on both the size and shape of the implant, and hence efforts were made to optimise implant geometry to maintain the beneficial stress level in a variety of loading scenarios. Hassler et al. ${ }^{90}$ showed that the target compressive stress level for maximum bone growth occurs at $1.8 \mathrm{MPa}$, levelling off to a control level at 2.8 MPa.

The jawbone experiences stress shielding which is an unpredictable biomechanical response to an applied load. Some theoretical work by Cowin ${ }^{91}$ has dealt with the problem of formulating Wolff's law in a quantitative fashion. In this theory, constitutive equations are developed which predict the remodelling response to a given stress. Stability considerations are invoked to obtain some constraints on the parameters in the constitutive equation.

\subsection{Material properties of jawbone}

The long-term clinical performance of a dental implant is dependant on the preservation of good quality bone surrounding the implant and a well-maintained interface between the biomaterial of the implant and the bone. Clinically, jawbone material properties are categorised into four types. Figure 8 shows that Types 1 and 2 offer high Young's modulus, while Types 3 and 4 have a thin cortex and low Young's modulus with low trabecular density. Jaffin and Berman ${ }^{92}$ stated that $90 \%$ of 1,054 implants placed were in Types 1 to 3 bones. Only $3 \%$ of these fixtures were lost; of the $10 \%$ of the fixtures placed in Type 4 bone, $35 \%$ failed.

\section{'[Insert figure 8 about here]’}

The mandibular is classified into cortical, crestal and trabecular tissue, it is a porous material with a complex microstructure. The quality and quantity of bone surrounding the implant influences the load transfer from implant to the jawbone. With the correct stress level within the jawbone, the correct amount of stress shielding will occur. Stress shielding is the mechanism that protects the jawbone from stresses that it might

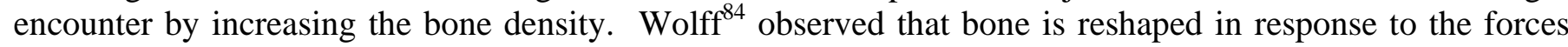
acting and this is referred to as Wolff's law. Ideally the selection of the correct implant design, will lead to maximum bone density increase.

Dechow et al. ${ }^{94}$ conducted an investigation into the use of bone plates on the mandible in four adult rhesus monkeys. At the beginning and end of the experiments, bone strain was recorded inferior to each bone plate during evoked maximal incisal clenching. After death, gross dimensions and density were measured. An ultrasonic technique was used to measure the material properties, including the elastic and shear moduli. Bone strain inferior to the plates was reduced by $34 \%$ to $53 \%$ after attachment of the thick plates. Long-term 
placement of bone plates, and the resulting stress shielding, were found to result in structural changes in the mandibular corpus.

Meijer et al. ${ }^{26}$ assumed isotropic, linear elastic and homogenous material properties for bone. But it has been stated by Patra et al. ${ }^{25}$ that the material of bone is neither homogeneous nor isotropic and should be modelled as being a porous material with a complex microstructure. It is recognized that cortical bone has better load bearing capabilities than trabecular bone. Lotz et al. ${ }^{95}$ have shown that cortical bone behaves anistropically, having both transverse and longitudinal module. At the microscopic level, bone is seen to be a composite. The collagen fibres form different arrangements depending on the type of bone. In compact bone, the collagen fibres are very directional. This leads to an orthotropic type material behaviour, such as a classic fibre/matrix composite material. Table 8 shows the assumed material properties for different types of bone used in various studies.

\section{'[Insert table 8 about here]'}

Zarone $^{28}$ investigated the biomechanical effect of mandibular functional flexure on stress build-up in implantsupported fixed restorations. Bony tissue was simulated by considering spongy (cancellous) bone to be replaced by an isotropic elastic material, while cortical bone was assumed to be isotropic, with the Young's modulus higher than that of the spongy bone (the physical properties of the materials are reported in Table 8). The ratio between spongy and cortical bone thicknesses was approximately 10, as estimated from the autoptic section of the mandible; spongy/cortical bone thicknesses were considered constant throughout the mandibular body. It was concluded, during Zarone's study, that a significant amount of stress in the more distal implants and the superstructure at the symphysis arises as a consequence of mandible functional flexure. The analysis of the stress distributions generated by the different restorative patterns suggests that a division of the superstructure at the level of the symphysis significantly restores the natural functional flexure of the mandible.

\subsection{Boundary conditions}

Most finite element analysis have only considered a small part of the jawbone surrounding the implant. $^{9,24,25,37,38,96}$ It has been found common during the construction of the finite element model, of the jawbone, to apply fixed constraints to the lower region of the jawbone. ${ }^{25,96}$

Patra et al. ${ }^{25}$ modelled bone support using muscle attachment with spring constraints as opposed to fixed constraints used in previous studies. Ishigaki et al. ${ }^{14}$ determined the directions of displacement constraints which were applied to the jawbone, according to the angles of the closing pathways of chopping type (C-type) and grinding type (G-type) chewing patterns. Directions of displacement constraints at the bottom of the mandible simulated the calculated directions of the closing pathways for C-type and G-type chewing patterns. The magnitude of the chewing force was selected as $200 \mathrm{~N}$. The sum of the nodal force on the mandibular occlusal surface was $200 \mathrm{~N}$ after displacement constraints were applied to the model. The models were restrained at the base of the maxillary first molar to avoid sliding of the entire model.

Ideally the entire jawbone structure should be evaluated for its contribution to the force exerted unto the dental implant. Hobkirk and Schwab ${ }^{97}$ analytically examined the mechanical effect of the contraction of the lateral pterygoid muscles (depresses and protracts mandible to open mouth) during opening and protrusive movements of the mandible. According to previous studies, the lateral pterygoid muscles pulling medially on the condyles mainly cause flexure of the mandible. It was assumed that the effect of these muscles is 
equivalent to two concentrated loads applied on the condyles along the horizontal rotational condylar axis. An arbitrary load of $10 \mathrm{~N}$ was applied in the x-direction on the mandibular model in the presence of different typologies of fixed prosthetic restorations.

\section{Modelling of interface}

The periodontal ligament (PDL) in natural teeth provides a spring like reaction. Creating an implant model with a PDL positioned between the implant and surrounding jawbone, has not been accomplished. Previous research has considered replicating the mechanical effect of the PDL by designing an abutment which provides a cushioning effect similar to that of the periodontal ligament. This abutment will compress by $0.5 \mathrm{~mm}$ when $78.5 \mathrm{~N}$ of axial load is applied to the implant. ${ }^{98}$ In this way it provides a 'buffering' action during the masticatory process to reduce the loading responsible for premature failure of implants. But for the required strength of the abutment screw, it was found that the abutment would become loose after it has been loaded several times.

Kaewsuriyathumrong and Soma ${ }^{99}$ investigated the stress created by the bite force and which is distributed along the tooth towards the PDL structure. 3D Finite element analysis was performed to examine the role of the tooth and PDL structures in the stress distribution. A mandibular first molar was constructed in the finite element model. The bite forces were measured by pressensor, and these bite force values were programmed to load down upon the occlusal surface of the model. When comparing the stress values of sampling points positioned between the root surfaces and the periphery of the PDL (the alveolar wall), all principal stresses for those of the PDL were less than those of the root surfaces. These findings revealed that the PDL, the dentine, and the pulp functioned in cooperation in stress reduction; and the sequences of enamel, dentine, and pulp influenced the pattern of stress distribution. The different material properties of the tooth structure in sequence were considered a very important factor for stress reduction and for the pattern of stress distribution, especially in the root. Skalak and Zhao ${ }^{100}$ stated that close apposition of bone to the titanium implant surface means that under loading, the interface moves as a unit without any relative motion; this is essential for the transmission of stress from the implant to the bone at all parts of the interface.

Stanford and Schneider ${ }^{101}$ considered how the material properties of bone on implant surfaces influence biological responses to loading. It was found that the osseous interface of a dental implant responds with a visco-elastic reaction. The titanium oxide layer, on the implant, provides a macroscopic and microscopic architecture which controls the shear strains at the interface.

\section{Recommendations for future research directions}

The various aspects associated with the finite element modelling and analysis of a dental implant and surrounding jawbone have been discussed in some detail in the preceding sections. Extensive research has been completed in the past that has led to significant findings relating to the biomechanical behaviour of the implant, jawbone and their interaction. An in-depth understanding of implant related problems, the development of an optimum implant design and the insertion technique still merit further and advanced investigation.

An initial recommendation involves the construction of a realistic jawbone model. For future research it might be recommended to identify a wider range of jawbone material properties according to the age and health condition of the patients. A possible method by which today's technology can be employed to perform such a task might include the use of CT image production and computer image processing technique. This 
technique has been used in hip joint research, ${ }^{102}$ however its application in dentistry is limited. There is a great potential in using CT-based image processing technique in dental implant research, as it is easy to distinguish between the cortical and trabecular bones from the CT images. Once a set of digital CT images of the jawbone are obtained, a precise 3D geometric model of jawbone and surrounding tissue can be readily established using image processing and reverse engineering approaches. ${ }^{27,103,104}$

The biomechanical response of the jawbone to a foreign object has not been modelled previously using numerical methods. The jawbone experiences stress shielding which is an unpredictable biomechanical response to an applied load. Ideally a computer programme/software can be developed which can predict the degree of stress shielding that the jawbone surrounding the implant experiences. The stress shielding produced by numerous jawbone types might also be evaluated through the use of CT-scanned images at set intervals during the healing stage. This will lead to an improved knowledge, for both the implant designer and implant surgeon, of how the jawbone will remodel in different implant placement insertion techniques, designs and loading conditions. An alternative method by which the stress shielding within the jawbone can be evaluated experimentally might be through the use of a photoelastic stress analysis technique. ${ }^{105}$

Numerous investigations have been aimed at determining the optimum geometry of an implant body. Some researchers indicated that the implant geometry had little or no effect on the success of the implant. ${ }^{38,45}$ While other researchers concluded that an implant diameter of $3.6-4.2 \mathrm{~mm}$ provides the highest success rate. ${ }^{13}$ A new methodology might be employed to determine the optimum combination of length, diameter, taperage, and implant cutting flute dimensions for each bone type. It is proposed that such a methodology might involve the use of the Application Programming Interface (API) function of commercial software. This software redevelopment work will lead to a 3D multi-parameter optimum design of the implant based on CAD parameterisation design technique. ${ }^{106}$

When an implant is surgically placed into the jawbone, the implant is mechanically screwed into a drilled hole of a smaller diameter. Large stresses will occur due to the torque applied in the process and the fact that the implant is cutting into the jawbone. As such, the stress condition in the jawbone will change accordingly. This phenomenon has not been researched adequately and the long-term effects of such stresses are still unclear and should therefore be investigated and the solution be sought so that undesirable stresses can be minimised.

The recommended future research areas, discussed above, will aid dentistry by providing an improved understanding of the effect that the implant geometry and orientation has on the stress distribution within the jawbone, during and after the implant is surgically placed into the jawbone. A reduction in the discomfort experienced by the patient during and after implant treatment might occur due to an improved method of surgically placing the implant into the bone.

\section{Conclusion}

Finite element analysis (FEA) has been used extensively to predict the biomechanical performance of various dental implant designs as well as the effect of clinical factors on the success of implantation. The principal difficulty in simulating the mechanical behaviour of dental implants is the modelling of the living human bone tissue and its response to applied mechanical forces. Research has been conducted on the design philosophy, length, diameter and shape of implants as well as the biomechanical bond formed between the implant and the 
jawbone. Such work has been mainly directed towards finding the most biocompatible materials with which the dental implants are constructed, in an attempt to reduce the potential risks of clinical failure. Despite the numerous research efforts in the field, no ideal design philosophy is available and the biological interaction at the interface between the implant material and the living tissue is not yet fully understood.

An in-depth understanding of stress profiles encountered by the implant and more importantly in the surrounding jawbone can be gained through the use of FEM. This increase in knowledge of stress distributions and magnitudes within the implant and surrounding jawbone will aid the optimisation of the implant design and insertion technique. It is of great importance that the clinician gains an understanding of the methodology, applications, and limitations of FEA in implant dentistry, and become more confident to interpret results of FEA studies and interpret these results to clinical situations.

\section{Acknowledgements}

This work was made possible by the collaborative support from Griffith's School of Engineering and School of Dentistry and Oral Health. A special thank goes to Mr John Mackay and Ms Jane Evans for their endless contribution.

\section{Appendix A}

\subsection{Tables}

Table 1. Summary of analysis software and analysis level.

\begin{tabular}{|c|c|c|c|c|c|c|c|c|c|}
\hline Source & $\begin{array}{l}\text { Papavasiliou } \\
\text { et al. }^{24}\end{array}$ & $\begin{array}{l}\text { Pierrisnard } \\
\text { et al. }^{18}\end{array}$ & Patra et al. ${ }^{25}$ & $\begin{array}{c}\text { Canay et } \\
\text { al. }^{9}\end{array}$ & $\begin{array}{c}\text { Meijer et } \\
\text { al. }^{26}\end{array}$ & $\begin{array}{c}\text { Borchers } \\
\text { and } \\
\text { Reichart. }_{7}^{2}\end{array}$ & $\begin{array}{l}\text { Zarone et } \\
\text { al. }^{28}\end{array}$ & $\begin{array}{c}\text { Lewinstein } \\
\text { et al. }^{29}\end{array}$ & $\begin{array}{c}\text { Menicucci et } \\
\text { al. }^{30}\end{array}$ \\
\hline Software & $\begin{array}{c}\text { COSMOS/M } \\
\text { Ver 1.61, } \\
\text { (SRAC) }\end{array}$ & CADSAP & $\begin{array}{l}\text { SDRC I-DEAS, } \\
\text { Hypermesh, } \\
\text { Ansys }\end{array}$ & SAP 90 & CAEDS & SAP IV & $\begin{array}{l}\text { AutoCAD, } \\
\text { SDRC I- } \\
\text { DEAS VI }\end{array}$ & ADINA & ADINA \\
\hline $\begin{array}{c}\text { Analysis } \\
\text { level }\end{array}$ & $3 \mathrm{D}$ & $3 \mathrm{D}$ & $2 \mathrm{D}$ & $2 \mathrm{D}$ & $3 \mathrm{D}$ & $3 \mathrm{D}$ & $3 \mathrm{D}$ & $2 \mathrm{D}$ & 2D and 3D \\
\hline
\end{tabular}


Table 2. Summary of finite element meshing schemes.

\begin{tabular}{|c|c|c|c|c|c|c|c|c|}
\hline \multicolumn{2}{|c|}{ Source } & $\begin{array}{c}\text { Papavasiliou } \\
\text { et al. }^{24}\end{array}$ & $\begin{array}{l}\text { Pierrisnard } \\
\text { et al. }^{18}\end{array}$ & $\begin{array}{l}\text { Canay et } \\
\text { al. }^{9}\end{array}$ & $\begin{array}{c}\text { Borchers } \\
\text { and } \\
\text { Reichart. }^{32}\end{array}$ & $\begin{array}{c}\text { Zarone et } \\
\text { al. }^{28}\end{array}$ & $\begin{array}{l}\text { Lewinstein } \\
\text { et al. }^{29}\end{array}$ & $\begin{array}{l}\text { Ishigaki } \\
\text { et al. }{ }^{14}\end{array}$ \\
\hline \multicolumn{2}{|c|}{ Element Type } & $\begin{array}{c}\text { Brick } \\
\text { (Not } \\
\text { symmetrical) }\end{array}$ & Brick & Brick & $\begin{array}{c}\text { Brick } \\
\text { (Hexahedral) }\end{array}$ & $\begin{array}{c}\text { Brick } \\
\text { (Solid } \\
\text { Linear and } \\
\text { Parabolic } \\
\text { wedge) }\end{array}$ & Brick & Brick \\
\hline \multirow[t]{2}{*}{$\begin{array}{c}\text { Implant } \\
\text { and } \\
\text { Jawbone }\end{array}$} & $\begin{array}{l}\text { Element } \\
\text { Number }\end{array}$ & 480 & $\begin{array}{l}4322 \text { to } \\
7766 \text { (6- } \\
12 \mathrm{~mm} \text { in } \\
\text { length) }\end{array}$ & 311 & 1129 & 2356 & 6441 & 1731 \\
\hline & $\begin{array}{c}\text { Node } \\
\text { Number }\end{array}$ & $* \mathrm{~N} / \mathrm{A}$ & $* \mathrm{~N} / \mathrm{A}$ & 295 & 1473 & $* \mathrm{~N} / \mathrm{A}$ & 26351 & 2269 \\
\hline
\end{tabular}

Table 3. Cumulative survival rate (CSR) of wide-bodied implants ${ }^{49}$.

\begin{tabular}{cc} 
Source & CSR (\%) \\
\hline Aparicio and Orozco. & Mx: 97.2 \\
Ivanoff et al. $^{45}$ & Md: 83.4 \\
& Mx: 86.3 \\
Tawil et al. $^{47}$ & Md: 73.0 \\
Shin et al. $^{49}$ & P: 96.9 \\
\end{tabular}

[2] Note: $\mathrm{Mx}=$ maxilla; $\mathrm{Md}=$ mandible; $\mathrm{P}=$ Posterior $\mathrm{Mx}$ and $\mathrm{Md}$

Table 4. Dental implant model specification.

\begin{tabular}{|c|c|c|c|c|c|c|c|c|}
\hline Source & $\begin{array}{c}\text { Papavasiliou } \\
\text { et al. }^{24}\end{array}$ & $\begin{array}{l}\text { Pierrisnard } \\
\text { et al. }^{18}\end{array}$ & $\begin{array}{l}\text { Patra et } \\
\text { al. }^{25}\end{array}$ & $\begin{array}{l}\text { Canay et } \\
\text { al. }^{9}\end{array}$ & $\begin{array}{l}\text { Meijer } \\
\text { et al. }\end{array}$ & $\begin{array}{c}\text { Borchers } \\
\text { and } \\
\text { Reichart }^{32}\end{array}$ & $\begin{array}{l}\text { Zarone } \\
\text { et al. }^{28}\end{array}$ & $\begin{array}{l}\text { Lewinstein } \\
\text { et al. }^{29}\end{array}$ \\
\hline Implant Design & $\begin{array}{c}\text { IMZ } \\
\text { (Interpore } \\
\text { International, } \\
\text { Irvine, CA, } \\
\text { USA) }\end{array}$ & $\begin{array}{c}\text { Nobel } \\
\text { Biocare AB } \\
\text { (Branemark } \\
\text { System) }\end{array}$ & $\begin{array}{c}\text { BUD } \\
\text { (parallel } \\
\text { profile } \\
\text { thread), } \\
\text { Branemark } \\
\text { (tapered } \\
\text { thread) }\end{array}$ & $\begin{array}{l}\text { ITI Bonefit } \\
\text { (Straumann) }\end{array}$ & $* \mathrm{~N} / \mathrm{A}$ & $\begin{array}{l}\text { Anchor- } \\
\text { type } \\
\text { endosteal }\end{array}$ & $* \mathrm{~N} / \mathrm{A}$ & $\begin{array}{c}\text { Branemark } \\
\text { System (IL } \\
\text { system) }\end{array}$ \\
\hline $\begin{array}{cc}\text { Length } \\
\text { Implan } \\
(\mathbf{m m})\end{array}$ & 11 & $6-12$ & 13 & $* \mathrm{~N} / \mathrm{A}$ & 20 & $* \mathrm{~N} / \mathrm{A}$ & 13 & 6 \\
\hline $\begin{array}{cc}\text { t Size } & \begin{array}{c}\text { Diameter } \\
(\mathrm{mm})\end{array} \\
\end{array}$ & 4 & $3.7-5$ & $* \mathrm{~N} / \mathrm{A}$ & $* \mathrm{~N} / \mathrm{A}$ & $3.7-5$ & $* \mathrm{~N} / \mathrm{A}$ & $3.2-5$ & $3.7-5$ \\
\hline Implant Material & $\begin{array}{c}\text { Titanium, Ti } \\
\text { (pure) }\end{array}$ & $\begin{array}{l}\text { Titanium, Ti } \\
\text { (pure) }\end{array}$ & $\begin{array}{l}\text { Titanium, } \\
\text { Ti (pure) }\end{array}$ & $\begin{array}{l}\text { Titanium, } \\
\text { Ti (pure) }\end{array}$ & $* \mathrm{~N} / \mathrm{A}$ & $\begin{array}{l}\text { Al2O3- } \\
\text { Ceramic }\end{array}$ & $* \mathrm{~N} / \mathrm{A}$ & $* \mathrm{~N} / \mathrm{A}$ \\
\hline
\end{tabular}


Table 5. Assumed material properties for titanium used in implant modelling.

\begin{tabular}{|c|c|c|c|c|c|c|c|c|}
\hline Source & $\begin{array}{c}\text { Papavasiliou } \\
\text { et al. }^{24}\end{array}$ & $\begin{array}{c}\text { Pierrisnard } \\
\text { et al. }^{18}\end{array}$ & $\begin{array}{c}\text { Patra et } \\
\text { al. }^{25}\end{array}$ & $\begin{array}{l}\text { Canay } \\
\text { et al. }{ }^{9} \\
\end{array}$ & $\begin{array}{l}\text { Meijer } \\
\text { et al. }^{26}\end{array}$ & $\begin{array}{c}\text { Zarone } \\
\text { et al. }^{28} \\
\end{array}$ & $\begin{array}{c}\text { Lewinstein } \\
\text { et al. }^{29}\end{array}$ & $\begin{array}{c}\begin{array}{c}\text { Menicucci } \\
\text { et al. }^{30}\end{array} \\
\end{array}$ \\
\hline $\begin{array}{l}\text { Young's } \\
\text { Modulus, E } \\
\text { (GPa) }\end{array}$ & 102.2 & 110 & 110 & 113.8 & 103.4 & 110 & 110 & 103.4 \\
\hline $\begin{array}{c}\text { Poisson's } \\
\text { Ratio, v }\end{array}$ & 0.35 & 0.3 & 0.33 & 0.35 & 0.35 & 0.29 & 0.33 & 0.35 \\
\hline
\end{tabular}

Table 6. Material properties of natural tooth.

\begin{tabular}{|c|c|c|c|c|c|c|c|c|}
\hline \multicolumn{2}{|c|}{ Source } & $\begin{array}{l}\text { Menicucci } \\
\text { et al. }^{30}\end{array}$ & $\begin{array}{c}\text { Davy et } \\
\text { al. }^{59}\end{array}$ & $\begin{array}{c}\text { Wright } \\
\text { and } \\
\text { Yettram }^{60}\end{array}$ & $\begin{array}{c}\text { Farah et } \\
\text { al. }^{61}\end{array}$ & $\begin{array}{c}\text { Farah et } \\
\text { al. }^{62}\end{array}$ & $\begin{array}{c}\text { Reinhardt } \\
\text { et al. }{ }^{63}\end{array}$ & $\begin{array}{l}\text { MacGregor } \\
\text { et al. }^{64}\end{array}$ \\
\hline \multirow[t]{2}{*}{ Enamel } & $\begin{array}{l}\text { Young's } \\
\text { Modulus, E } \\
(\mathrm{GPa})\end{array}$ & 84100 & 41400 & 46900 & 82500 & 84000 & $* \mathrm{~N} / \mathrm{A}$ & $* \mathrm{~N} / \mathrm{A}$ \\
\hline & $\begin{array}{l}\text { Poisson's } \\
\text { Ratio, v }\end{array}$ & 0.2 & 0.3 & 0.3 & 0.33 & 0.33 & $* \mathrm{~N} / \mathrm{A}$ & $* \mathrm{~N} / \mathrm{A}$ \\
\hline \multirow[t]{2}{*}{ Dentin } & $\begin{array}{l}\text { Young's } \\
\text { Modulus, E } \\
(\mathrm{GPa}) \\
\end{array}$ & 18600 & $* \mathrm{~N} / \mathrm{A}$ & $* \mathrm{~N} / \mathrm{A}$ & $* \mathrm{~N} / \mathrm{A}$ & $* \mathrm{~N} / \mathrm{A}$ & 18600 & 18000 \\
\hline & $\begin{array}{c}\text { Poisson's } \\
\text { Ratio, v }\end{array}$ & 0.31 & $* \mathrm{~N} / \mathrm{A}$ & $* \mathrm{~N} / \mathrm{A}$ & $* \mathrm{~N} / \mathrm{A}$ & $* \mathrm{~N} / \mathrm{A}$ & 0.31 & 0.31 \\
\hline
\end{tabular}

[4] $*$ N/A - information not available.

Table 7. Typical load level. ${ }^{43}$

\begin{tabular}{ccc}
\hline Direction & Specification & Load level (Mean +/- SD) (N) \\
\hline Vertical & Intrusion force & $70+/-15$ \\
Transverse & Buccal moment & $170+/-50$ \\
& Oral moment & $90+/-12$ \\
& Buccal transverse force at crestal bone margin & $21+/-6$ \\
Mesiodistal & Oral transverse force at crestal bone margin & $11+/-1.5$ \\
& Mesial moment & $<52+/-26$ \\
& Distal moment & $35+/-17$ \\
\hline
\end{tabular}


Table 8. Assumed material properties for different types of bone.

\begin{tabular}{|c|c|c|c|c|c|c|c|c|c|c|c|c|}
\hline \multicolumn{2}{|c|}{ Source } & $\begin{array}{c}\text { Papavasiliou } \\
\text { et al. }^{24}\end{array}$ & $\begin{array}{l}\text { Pierrisnard } \\
\text { et al. }^{18}\end{array}$ & $\begin{array}{c}\text { Patra } \\
\text { et } \\
\text { al. }^{25}\end{array}$ & $\begin{array}{l}\text { Canay } \\
\text { et al. }\end{array}$ & $\begin{array}{c}\text { Meijer et } \\
\text { al. }^{26}\end{array}$ & $\begin{array}{c}\text { Borchers } \\
\text { and } \\
\text { Reichart. }^{32}\end{array}$ & $\begin{array}{l}\text { Zarone } \\
\text { et al. }^{28}\end{array}$ & $\begin{array}{c}\text { Lewinstein } \\
\text { et al. }^{29}\end{array}$ & $\begin{array}{l}\text { Menicucci } \\
\text { et al. }^{30}\end{array}$ & $\begin{array}{l}\text { Farah } \\
\text { et al. }\end{array}$ & $\begin{array}{c}\text { MacGregor } \\
\text { et al. }{ }^{64}\end{array}$ \\
\hline \multirow{2}{*}{$\begin{array}{c}\text { Cortical } \\
\text { Bone }\end{array}$} & $\begin{array}{c}\text { Young } \\
\text { Modulus, } \\
\text { E (GPa) } \\
\end{array}$ & 13.7 & 14 & 7.5 & 19.73 & 13.7 & 13.7 & 15 & 20 & 13.7 & 10 & $* \mathrm{~N} / \mathrm{A}$ \\
\hline & $\begin{array}{l}\text { Poissons } \\
\text { Ratio, v }\end{array}$ & 0.3 & 0.35 & 2.7 & 0.3 & 0.3 & 0.3 & 0.25 & 0.3 & 0.3 & 0.3 & $* \mathrm{~N} / \mathrm{A}$ \\
\hline \multirow{2}{*}{$\begin{array}{c}\text { Cancellous } \\
\text { Bone }\end{array}$} & $\begin{array}{c}\text { Young } \\
\text { Modulus, } \\
\text { E (GPa) }\end{array}$ & 7.93 & 2.5 & $* \mathrm{~N} / \mathrm{A}$ & $* \mathrm{~N} / \mathrm{A}$ & 1.37 & $* \mathrm{~N} / \mathrm{A}$ & 1.5 & $* \mathrm{~N} / \mathrm{A}$ & 1.37 & $* \mathrm{~N} / \mathrm{A}$ & $* \mathrm{~N} / \mathrm{A}$ \\
\hline & $\begin{array}{l}\text { Poissons } \\
\text { Ratio, v }\end{array}$ & 0.3 & 0.3 & $* \mathrm{~N} / \mathrm{A}$ & $* \mathrm{~N} / \mathrm{A}$ & 0.3 & $* \mathrm{~N} / \mathrm{A}$ & 0.29 & $* \mathrm{~N} / \mathrm{A}$ & 0.3 & $* \mathrm{~N} / \mathrm{A}$ & $* \mathrm{~N} / \mathrm{A}$ \\
\hline \multirow{2}{*}{$\begin{array}{c}\text { Trabecular } \\
\text { Bone }\end{array}$} & $\begin{array}{c}\text { Young } \\
\text { Modulus, } \\
\text { E (GPa) } \\
\end{array}$ & $* \mathrm{~N} / \mathrm{A}$ & $* \mathrm{~N} / \mathrm{A}$ & 0.5 & $* \mathrm{~N} / \mathrm{A}$ & $* \mathrm{~N} / \mathrm{A}$ & $* \mathrm{~N} / \mathrm{A}$ & $* \mathrm{~N} / \mathrm{A}$ & $* \mathrm{~N} / \mathrm{A}$ & $* \mathrm{~N} / \mathrm{A}$ & $* \mathrm{~N} / \mathrm{A}$ & 0.25 \\
\hline & $\begin{array}{l}\text { Poissons } \\
\text { Ratio, v }\end{array}$ & $* \mathrm{~N} / \mathrm{A}$ & $* \mathrm{~N} / \mathrm{A}$ & 0.3 & $* \mathrm{~N} / \mathrm{A}$ & $* \mathrm{~N} / \mathrm{A}$ & ${ }^{*} \mathrm{~N} / \mathrm{A}$ & $* \mathrm{~N} / \mathrm{A}$ & $* \mathrm{~N} / \mathrm{A}$ & $* \mathrm{~N} / \mathrm{A}$ & $* \mathrm{~N} / \mathrm{A}$ & 0.3 \\
\hline
\end{tabular}

[5] $*$ N/A - information not available.

\subsection{Figures legends}

Figure 1. Three-dimensional view of dental implant produced by Neoss (Courtesy of Neoss Australia Pty Ltd).

Figure 2. Cross-sectional view of a natural tooth and a dental implant (www-hsc.usc.edu).

Figure 3. Different loading directions applied to a simplified implant and jawbone model.

Figure 4. Vertical, transverse and mesiodistal loading directions.

Figure 5. Bite force direction.

Figure 6. Horizontal, vertical and oblique forces.

Figure 7. Submerged and non-submerged implants.

Figure 8. Correlation between Young's modulus and apparent bone densities. ${ }^{93}$

\subsubsection{Figures}

Figure 1. (Reference 1)

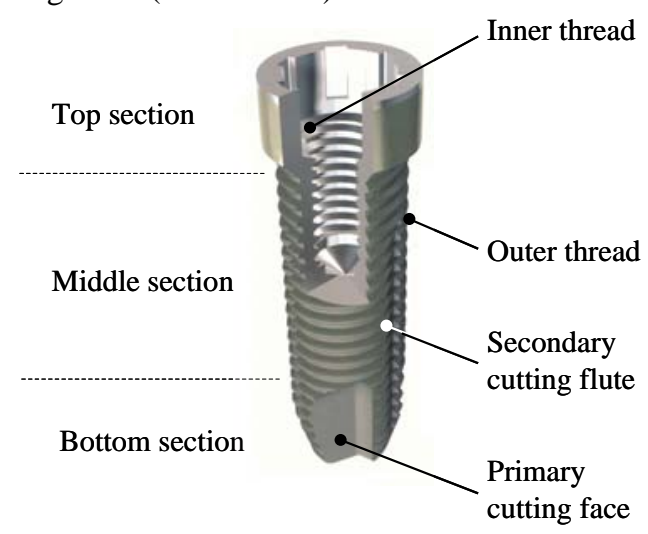


Figure 2. (Reference 2)

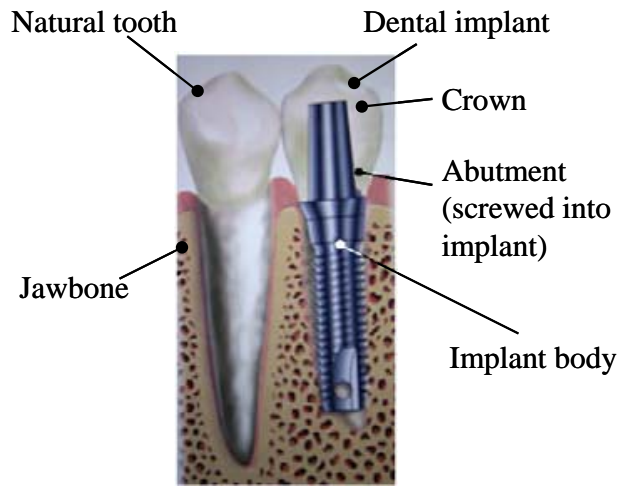

Figure 3.
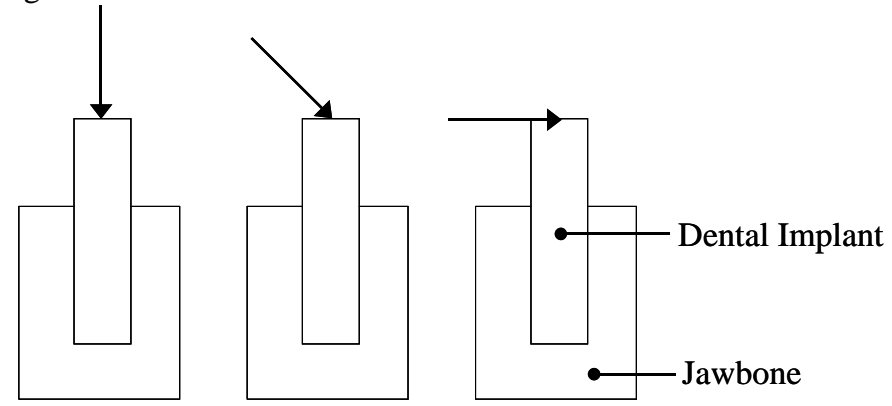

Vertical Load Oblique Load Horizontal Load

Figure 4.

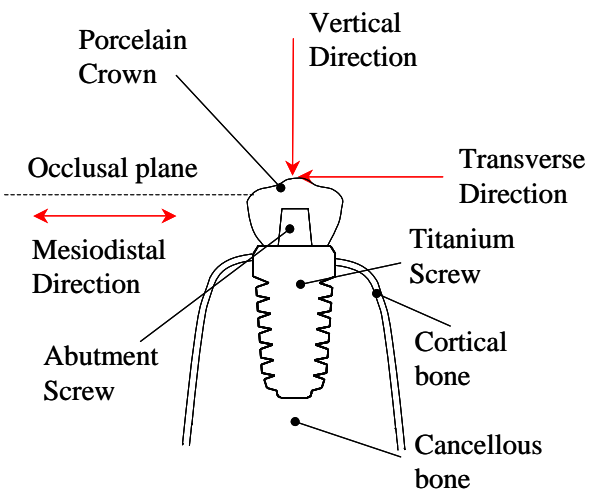


Figure 5.

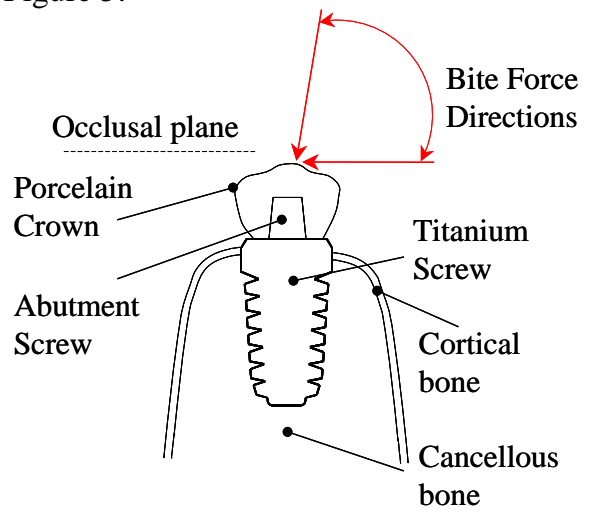

Figure 6.

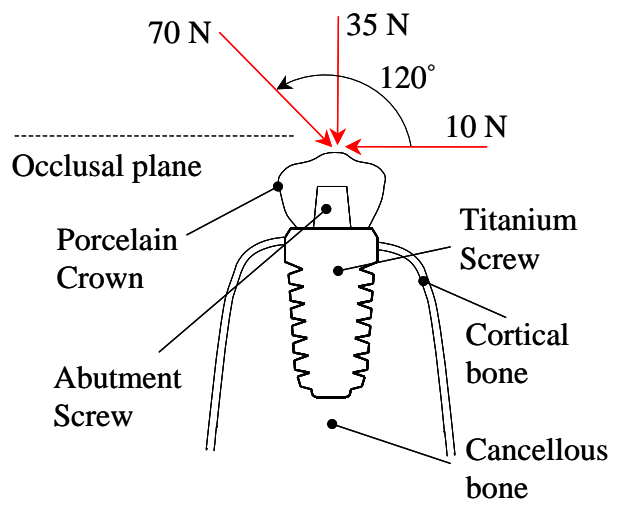

Figure 7.

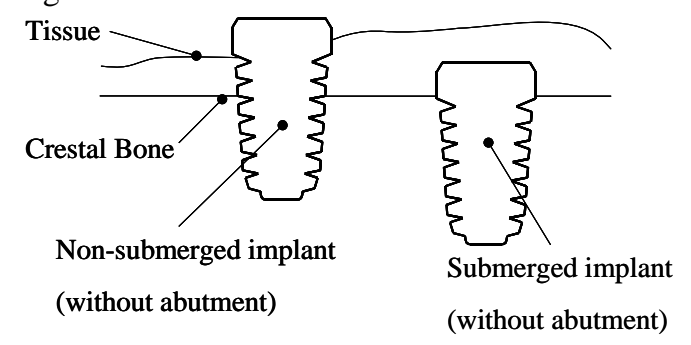


Figure 8. (Rho et al. ${ }^{93}$ ).

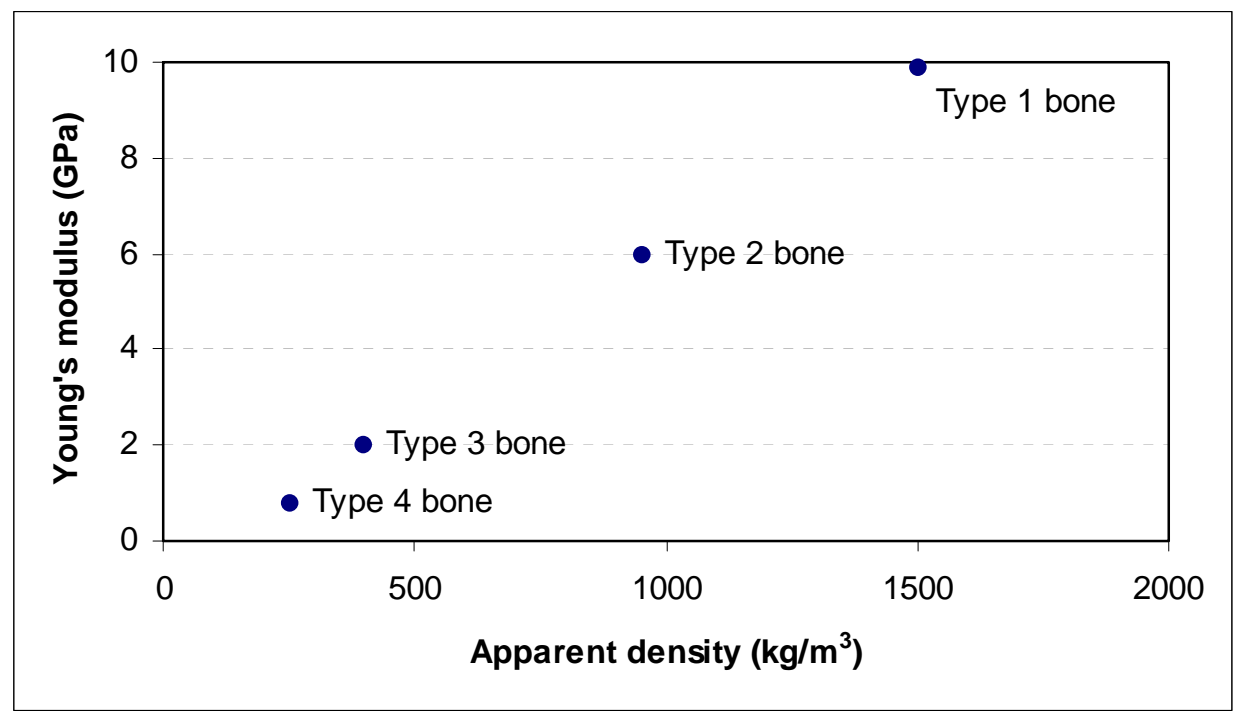

\section{References}

[1] Neoss Australia Pty Ltd

[2] University of Southern California. Available online at: www-hsc.usc.edu (accessed 25 November 2004).

[3] Dental Materials: Properties and Selection, W.J. O'Brien, Quintessence Publishing, Chicago; London, 1989, (ISBN 0867151994).

[4] Ergatoudis, I., Irons, B.M., and Zienkiewicz, O.C., 1968, Curved, isoparametric, quadrilateral elements for finite element analysis. International Journal of Solids and Structures, 4(1), 31-42.

[5] Rzemieniecki, J.S., 1969, Theory of matrix structural analysis. Journal of Sound and Vibration, 10(2), 358-359.

[6] Akca, K., and Iplikcioglu, H., 2001, Finite element stress analysis of the influence of staggered versus straight placement of dental implants. International Journal of Oral \& Maxillofacial Implants, 16(5), 722-730.

[7] Akca, K., Cehreli, M.C., and Iplikcioglu, H.A., 2002, Comparison of three-dimensional finite element stress analysis with in vitro strain gauge measurements on dental implants. International Journal of Prosthodontics, 15(2), 115-121.

[8] Akpinar, I., Anil, N., and Parnas, L., 2000, A natural tooth's stress distribution in occlusion with a dental implant. Journal of Oral Rehabilitation, 27(6), 538-545.

[9] Canay, S., Hersek, N., Akpinar, I., and Asik, Z., 1996, Comparison of stress distribution around vertical and angled implants with finiteelement analysis. Quintessence International, 27(9), 591-598.

[10] DeTolla, D.H., Andreana, S., Patra, A., Buhite, R., and Comella, B., 2000, Role of the finite element model in dental implants. Journal of Oral Implantol, 26(2), 77-81.

[11] Eskitascioglu, G., Usumez, A., Sevimay, M., Soykan, E., and Unsal, E., 2004, The influence of occlusal loading location on stresses transferred to implant-supported prostheses and supporting bone: A three-dimensional finite element study. Journal of Prosthetic Dentistry, 91(2), 144-150.

[12] Geng, J.P., Tan, K.B., and Liu, G.R., 2001, Application of finite element analysis in implant dentistry: a review of the literature. Journal of Prosthetic Dentistry, 85(6), 585-598.

[13] Himmlova, L., Dostalova, T., Kacovsky, A., and Konvickova, S., 2004, Influence of implant length and diameter on stress distribution: a finite element analysis. Journal of Prosthetic Dentistry, 91(1), 20-25.

[14] Ishigaki, S., Nakano, T., Yamada, S., Nakamura, T., and Takashima. F., 2003, Biomechanical stress in bone surrounding an implant under simulated chewing. Clinical Oral Implants Research, 14(1), 97-102.

[15] Ismail, Y.H., Pahountis, L.N., and Fleming, J.F., 1987, Comparison of two-dimensional and three-dimensional finite element analysisof a blade implant. International Journal of Oral Implantol, 4, 25-31.

[16] Nagasao, T., Kobayashi, M., Tsuchiya, Y., Kaneko, T., and Nakajima, T., 2002, Finite element analysis of the stresses around endosseous implants in various reconstructed mandible models. Journal of Craniomaxillofac Surgery, 30(3), 170-177.

[17] Nagasao, T., Kobayashi, M., Tsuchiya, Y., Kaneko, T., and Nakajima, T., 2003, Finite element analysis of the stresses around fixtures in various reconstructed mandibular models--part II (effect of horizontal load). Journal of Cranio-Maxillo-Facial Surgery, 31(3), 168-175.

[18] Pierrisnard, L., Hure, G., Barquins, M., and Chappard, D., 2002, Two dental implants designed for immediate loading: a finite element analysis. International Journal of Oral Maxillofacial Implants, 17(3), 353-362. 
[19] Plikçiolu, H., and Akça, K., 2002, Comparative evaluation of the effect of diameter, length and number of implants supporting three-unit fixed partial prostheses on stress distribution in the bone. Journal of Dentistry, 30(1), 41-46.

[20] Rieger, R., Mayberry, M., and Brose, M.O., 1990, Finite element analysis of six endosseous implants. Journal of Prosthetic Dentistry, 63(6), 671-676.

[21] Stegaroiu, R., Kusakari, H., Nishiyama, S., and Miyakawa, O., 1998, Influence of prosthesis material on stress distribution in bone and implant: a 3-dimensional finite element analysis. International Journal of Oral Maxillofacial Implants, 13(6), 781-790.

[22] Waskewicz, V.J., Ostrowski, G.A., and Parks, J.S., 1994, Photoelastic analysis of stress distribution transmitted from a fixed prosthesis attached to osseointegrated implants. Journal of Oral and Maxillofacial Implants, 9(4), 405-411.

[23] Watanabe, F., Hata, Y., Komatsu, S., Ramos, T.C., and Fukuda, H., 2003, Finite element analysis of the influence of implant inclination, loading position, and load direction on stress distribution. Odontology, 9(1), 31-36.

[24] Papavasiliou, G., Kamposiora, P., Bayne, S.C., and Felton, D.A., 1997, 3D-FEA of osseointegration percentages and patterns on implant-bone interfacial stresses. Journal of Dentistry, 25(6), 485-491.

[25] Patra, A.K., DePaolo, J.M., D'Souza, K.S., DeTolla, D., and Meenaghan, M.A., 1998, Guidelines for analysis and redesign of dental implants. Implant Dentistry, 7(4), 355-368.

[26] Meijer, H.J., Starmans, F.J., Steen, W.H., and Bosman, F., 1993, A three-dimensional, finite-element analysis of bone around dental implants in an edentulous human mandible. Archives of Oral Biology, 38(6), 491-496.

[27] George, K.K., Rasha, A.N., 2001, Adaptive reconstruction of bone geometry from serial cross-sections. Artificial Intelligence in Engineering. 15, 227-239.

[28] Zarone, F., Apicella, A., Nicolais, L., Aversa, R., and Sorrentino, R., 2003, Mandibular flexure and stress build-up in mandibular full-arch fixed prostheses supported by osseointegrated implants. Clinical Oral Implants Research, 14(1), 103-114.

[29] Lewinstein, I., Banks-Sills, L., and Eliasi, R., 1995, A finite element analysis of a new system (IL) for supporting an implant-retained cantilever prosthesis. International Journal of Oral Maxillofacial Implants, 10(3), 355-366.

[30] Menicucci, G., Mossolov, A., Mozzati, M., Lorenzetti, M., and Preti, G., 2002, Tooth-implant connection: some biomechanical aspects based on finite element analyses. Clinical Oral Implants Research, 13(3), 334-341.

[31] Kohal, R.J., Papavasiliou, G., Kamposiora, P., Tripodakis, A., and Strub, J.R., 2002, Three-dimensional computerized stress analysis of commercially pure titanium and yttrium-partially stabilized zirconia implants. International Journal of Prosthodontics, 15(2), $189-194$.

[32] Borchers, L., and Reichart, P., 1983, Three-dimensional stress distribution around a dental implant at different stages of interface development. Journal of Dentistry Research, 62(2), 155-159.

[33] Mihalko, W.M., May, T.C., Kay, J.F., and Krause, W.R., 1992, Finite element analysis of interface geometry effects on the crestal bone surrounding a dental implant. Journal of Implant Dentistry, 1(3), 212-217.

[34] Nishihara, K., and Nakagiri, S., 1994, Biomechanical studies on newly tailored artificial dental root. Biomedical Material Engineering, 4(3), 141-149.

[35] Rho, J.Y., Ashman, R.B., and Turner, C.H., 1993, Young's modulus of trabecular and cortical bone material: ultrasonic and microtensile measurements. Journal of Biomechanics, 26(2), 111-119.

[36] O'Mahony, A., Bowles, Q., Woolsey, G., Robinson, S.J., and Spencer, P., 2000, Stress distribution in the single-unit osseointegrated dental implant: finite element analyses of axial and off-axial loading. Implant Dentistry, 9(3), 207-218.

[37] Tada, S., Stegaroiu, R., Kitamura, E., Miyakawa, O., and Kusakari, H., 2003, Influence of implant design and bone quality on stress/strain distribution in bone around implants: a 3-dimensional finite element analysis. International Journal of Oral Maxillofacial Implants, 18(3), 357-368.

[38] Pierrisnard, L., Renouard, F., Renault, P., and Barquins, M., 2003, Influence of implant length and bicortical anchorage on implant stress distribution. Clinical Implant Dentistry Related Research, 5(4), 254-262.

[39] Richter, E.J., 1998, In vivo horizontal bending moments on implants. The International Journal of Oral \& Maxillofacial Implants, 13(2), 232244.

[40] Yokoyama, S., Wakabayashi, N., Shiota, M., and Ohyama, T., 2004, The influence of implant location and length on stress distribution for three-unit implant-supported posterior cantilever fixed partial dentures. Journal of Prosthetic Dentistry, 91(3), 234-240.

[41] Siegele, D., and Soltesz, U., 1989, Numerical investigations of the influence of implant shape on stress distribution in the jaw bone. International Journal of Oral Maxillofacial Implants, 4(4), 333-340.

[42] Holmgren, E.P., Seckinger, R.J., Kilgren, L.M., and Mante, F., 1998, Evaluating parameters of osseointegrated dental implants using finite element analysis--a two-dimensional comparative study examining the effects of implant diameter, implant shape, and load direction. Journal of Oral Implantol, 24(2), 80-88.

[43] Aparicio, C., and Orozco, P., 1998, Use of 5-mm-diameter implants: Periotest values related to a clinical and radiographic evaluation. Clinical Oral Implants Research, 9(6), 398-406.

[44] Iplikcioglu, H., and Akca, K., 2002, Comparative evaluation of the effect of diameter, length and number of implants supporting three-unit fixed partial prostheses on stress distribution in the bone. Journal of Dentistry, 30(1), 41-46.

[45] Ivanoff, C.J., Grondahl, K., Sennerby, L., Bergstrom, C., and Lekholm, U., 1999, Influence of variations in implant diameters: a 3- to 5-year retrospective clinical report. International Journal of Oral Maxillofacial Implants, 14(2), 173-180.

[46] Misch, C.E., 1999, Implant design considerations for the posterior regions of the mouth. Implant Dentistry, 8(4), 376-386.

[47] Tawil, G., Mawla, M., and Gottlow, J., 2002, Clinical and radiographic evaluation of the 5-mm diameter regular-platform Branemark fixture: 2- to 5-year follow-up. Clinical Implant Dentistry Related Research, 4(1), 16-26.

[48] Zhang, L., Zhou, Y., and Meng, W., 2000, A three-dimensional finite element analysis of the correlation between lengths and diameters of the implants of fixed bridges with proper stress distribution. Hua Xi Kou Qiang Yi Xue Za Zhi, 18(4), 229-231. 
[49] Shin, S.W., Bryant, S.R., and Zarb, G.A., 2004, A retrospective study on the treatment outcome of wide-bodied implants. International Journal of Prosthodon, 17(1), 52-58.

[50] Mailath, G., Stoiber, B., Watzek, G., and Matejka, M., 1989, Bone resorption at the entry of osseointegrated implants--a biomechanical phenomenon. Finite element study. Journal of Oral Implantol, 24(2), 80-88.

[51] Astrand, P., Billstrom, C., Feldmann, H., Fischer, K., Henricsson, V., Johansson, B., Nystrom, E., and Sunzel, B., 2003, Tapered implants in jaws with soft bone quality: a clinical and radiographic 1-year study of the Branemark System Mark IV fixture. Clinical Implant Dentistry Related Research, 5(4), 213-218.

[52] Nobel Biocare. Availible online at: www.nobelbiocare.com (accessed 10 December 2004).

[53] Friberg, B., Jisander, S., Widmark, G., Lundgren, A., Ivanoff, C.J., Sennerby, L., and Thoren, C., 2003, One-year prospective three-center study comparing the outcome of a 'soft bone implant' (prototype Mk IV) and the standard Branemark implant. Clinical Implant Dentistry Related Research, 5(2), 71-77.

[54] O'Sullivan, D., Sennerby, L., and Meredith, N., 2004, Influence of implant taper on the primary and secondary stability of osseointegrated titanium implants. Clinical Oral Implants Research, 15(4), 474-480.

[55] Meredith, N., Shagaldi, F., Alleyne, D., Sennerby, L., and Cawley, P., 1997, The application of resonance frequency measurements to study the stability of titanium implants during healing in the rabbit tibia. Clinical Oral Implants Research, 8(3), 234-243.

[56] Osstel. Availible online at: www.integrationdiagnostics.com/pro/pro_range.html (accessed 29 December 2004).

[57] Hedia, H.S., and Mahmoud, N.A., 2004, Design optimization of functionally graded dental implant. Biomedical Material Engineering, 14(2), 133-43.

[58] Moroi, H.H., Okimoto, K., Moroi, R., and Terada, Y., 1993, Numeric approach to the biomechanical analysis of thermal effects in coated implants. International Journal of Prosthodontics, 6(6), 564-572.

[59] Davy, D.T., Dilley, G.L., and Krejci, R.F., 1981, Determination of stress patterns in root-filled teeth incorporating various dowel designs. Journal of Dentistry Research, 60(7), 1301-1310.

[60] Wright, K.W., and Yettram, A.L., 1979, Reactive force distributions for teeth when loaded singly and when used as fixed partial denture abutments. Journal of Prosthetic Dentistry, 42(4), 411-416.

[61] Farah, J.W., Craig, R.G., and Meroueh, K.A., 1989, Finite element analysis of three- and four-unit bridges. Journal of Oral Rehabilitation, 16(6), 603-611.

[62] Farah, J.W., Hood, J.A., and Craig, R.G., 1974, Stresses and deflections in the floor of model cavity preparations. Journal of Oral Rehabilitation, 1(2), 207-215.

[63] Reinhardt, R.A., Pao, Y.C., and Krejci, R.F., 1984, Periodontal ligament stresses in the initiation of occlusal traumatism. Journal of Periodontal Research, 19(3), 238-246.

[64] MacGregor, A.R., Miller, T.P., and Farah, J.W., 1980, Stress analysis of mandibular partial dentures with bounded and free-end saddles. Journal of Dentistry, 8(1), 27-34.

[65] Haraldson, T., Jemt, T., Stalblad, P.A., and Lekholm, U., 1988, Oral function in subjects with overdentures supported by osseointegrated implants. Scandinavian Journal of Dental Research, 96(3), 235-242.

[66] Koolstra, J.H., van Eijden, T.M., Weijs, W.A., and Naeije, M., 1988, A three-dimensional mathematical model of the human masticatory system predicting maximum possible bite forces. Journal of Biomechanics, 21(7), 563-576.

[67] Barbier, L., Vander Sloten, J., Krzesinski, G., Schepers, E., and Van der Perre, G., 1998, Finite element analysis of non-axial versus axial loading of oral implants in the mandible of the dog. Journal of Oral Rehabilitation, 25(11), 847-858.

[68] Brunski, J.B., 1988, Biomechanics of oral implants: future research directions. Journal of Dental Education, 52(12), $775-787$.

[69] Kirsch, A., and Ackermann K.L., 1989, The IMZ osteointegrated implant system. Dental Clinic of North America, 33(4), 733-791.

[70] Sullivan, D.Y., 1986, Prosthetic considerations for the utilization of osseointegrated fixtures in the partially edentulous arch. International Journal of Oral Maxillofacial Implants, 1(1), 39-45.

[71] Wennerberg, B., Albrektsson, A., Andersson, T., 1994, Design and surface characteristics of 13 commercially available oral implant systems. International Journal of Oral \& Maxillofacial Implants, 8(6), 622-633.

[72] http://www.wheelessonline.com/ortho/cement_mixing_technique_for_tjr (accessed 2nd January 2005)

[73] http://www.maryland-implants.com/slavkin_implants.htm (accessed 23rd December 2004)

[74] http://niznick.net/newsletter_8.htm (accessed 12th December 2004)

[75] http://www.partisanmgmt.com/implamed/implamed.htm (accessed 15th January 2005)

[76] http://www.calcitek.com/zimmerDental.asp (accessed 25th February 2005)

[77] http://www.3i.com (accessed 20th November 2004)

[78] http://niznick.com/company/1989/cl_announcement_disclaimer_02.htm (accessed 4th March 2005)

[79] Hermann, J.S., Schoolfield, J.D., Nummikoski, P.V., Buser, D., Schenk, R.K., and Cochran, D.L., 2001, Crestal bone changes around titanium implants: a methodologic study comparing linear radiographic with histometric measurements. International Journal of Oral Maxillofacial Implants, 16(4), 475-485.

[80] Ronold, H.J., Lyngstadaas, S.P., and Ellingsen, J.E., 2003, Analysing the optimal value for titanium implant roughness in bone attachment using a tensile test. Biomaterials, 24(25), 4559-4564.

[81] Wennerberg, A., and Albrektsson, T., 2000, Suggested guidelines for the topographic evaluation of implant surfaces. International Journal of Oral \& Maxillofacial Implants, 15(3), 331-344.

[82] www.cee.hw.ac.uk/ gmg/rough_surf/surfruf.htm (accessed 29 December 2004).

[83] Hansson, S., 1999, The implant neck: smooth or provided with retention elements. A biomechanical approach. Clinical Oral Implants Research, 10(5), 394-405.

[84] Wolff, J., 1986, The law of bone remodelling. Springer, Berlin. 
[85] Pelsoczi, K.I., Bereznai, M., Toth, Z., Turzo, K., Radnai, M., Bor, Z., Fazekas, A., 2004, Surface modifications of titanium implant material with excimer laser for more effective osseointegration. Fogorv S, 97(6), 231-7.

[86] Misch, C.E., Wang, H.L., Misch, C.M., Sharawy, M., Lemons, J., Judy, K.W., 2004, Rationale for the application of immediate load in implant dentistry: part II. Implant Dentistry, 13(4), 310-21.

[87] Rokni, S., Todescan, R., Watson, P., Pharoah, M., Adegbembo, A.O., Deporter, D., 2005, An assessment of crown-to-root ratios with short sintered porous-surfaced implants supporting prostheses in partially edentulous patients. International Journal of Oral Maxillofacial Implants, 20(1), 69-76.

[88] http://www.rjsteinerdds.com/html/endopore.htm (accessed 10th March 2005)

[89] Maniatopoulos, C., Pilliar, R.M., Smith, D.C., 1986, Threaded Versus Porous-Surfaced Designs for Implant Stabilization in Bone-Endodontic Implant Model. Journal of Biomedical Materials Research, 20(9), 1309-1333.

[90] Hassler, C.R., Rybicki, E.F., Cummings, K.D., and Clark, L.C., 1980, Quantification of bone stresses during remodeling. Journal of Biomechanics, 13(2), 185-190.

[91] Cowin, S.C., and Hegedus, D.H., 1976, Bone Remodeling I: Theory of adaptive elasticity. Journal of Elasticity, 6, 313-326.

[92] Jaffin, R.A., and Berman, C.L., 1991, The excessive loss of Branemark fixtures in type IV bone: a 5-year analysis. Journal of Periodontol, 62(1), 2-4.

[93] Dechow, P.C., Ellis, E., Throckmorton, G.S., 1995, Structural properties of mandibular bone following application of a bone plate. Journal of Oral Maxillofacial Surgery, 53(9), 1044-1051.

[94] Lotz, J.C., Gerhart, T.N., and Hayes, W.C., 1991, Mechanical properties of metaphyseal bone in the proximal femur. Journal of Biomechanics, 24(5), 317-329.

[95] Geng, J.P., Ma, Q.S., Xu, W., Tan, K.B.C., and Liu, G.R., 2004, Finite element analysis of four thread-form configurations in a stepped screw implant. Journal of Oral Rehabilitation, 31(3), 233-239.

[96] Hobkirk, J.A., and Schwab, J., 1991, Mandibular deformation in subjects with osseointegrated implants. International Journal of Oral Maxillofacial Implants, 6(3), 319-328.

[97] Lindquist, L.W., Carlsson, G.E., and Jemt, T., 1996, A prospective 15year followup study of mandibular fixed prostheses supported by osseointegrated implants. Clinical Oral Implants Research, 7(4), 329.

[98] Kaewsuriyathumrong, C., and Soma, K., 1993, Stress of tooth and PDL structure created by bite force. Bull Tokyo Medical Dentistry University, 40(4), 217-232.

[99] Skalak, R., and Zhao, Y., 2000, Similarity of stress distribution in bone for various implant surface roughness heights of similar form. Clinical Implant Dentistry Related Research, 2(4), 225-230.

[100] Stanford, C.M., and Schneider, G.B., 2004, Functional behaviour of bone around dental implants. Gerodontology, 21(2), 71-77.

[101] van Rietbergen, B., Huiskes, R., Weinans, H., Sumner, D.R., Turner, T.M., Galante, J.O., 1993, The mechanism of bone remodeling and resorption around press-fitted THA stems. Journal of Biomechanics, 26, 369-382.

[102] Liu, S., Ma, W., 1999, Seed-growing segmentation of 3-D surfaces from CT-contour data. Computer-Aided Design. 31, 517-536.

[103] Marco, V., Cinzia, Z., Luisa, P., 1998, TRI2SOLID: an application of reverse engineering methods to the creation of CAD models of bone segments. Computer Methods and Programs in Biomedicine. 56, 211-220.

[104] Wei, S., Pallavi, L., 2002, Recent development on computer aided tissue engineering -a review. Computer Methods and Programs in Biomedicine. 67, 85-103.

[105] Waskewicz, V.J., Ostrowski. G.A., Parks, J.S. (1994), "Photoelastic analysis of stress distribution transmitted from a fixed prosthesis attached to osseointegrated implants". Journal of Oral and Maxillofacial Implants. 9(4): 405-411.

[106] Vena, P., Verdonschot, N., Contro, R., Huiskes, R., 2000, Sensitivity Analysis and Optimal Shape Design for Bone-Prosthesis Interfaces in a Femoral Head Surface Replacement. Computer Methods Biomechanics and Biomedical Engineering, 3(3), 245-256. 